BUREAU OF STANDARDS.

WASHINGTON
Letter

Circular

LC $12 I$

Nay $12, \quad 1824$

PUBLICATIONS ON FLECTRODFFOSITION FRON THE BUREAU OF STANDARDS

The availability of publications is indicated as follows:

A - Available for free distribution. Address request to Bureau of Standards, (Attention of V-G).

B - May be secured by sending list price to Superintendent of Documents, Government Printing Office, Vashington, D.G. No not send money to the Bureau of standards.

C - Not available excent in libraries, etc.

I. General

C - Factors Governing the Structure of Electroderosited Metals, W. Blum - Trans. Am. Electrochem. Soc, 36, 213 (1919).

C - The Structure and Properties of Alternately Flectrodeposited Metals, W. Blum. Trans. Am. Flectrochen, Soc, 40, 137, (1921) and Chem. wet. Fng. 25,96 (1921).

A - Abstract of preceding article. Bureau of Standards Letter Circular LC 33 (192I).

C - The Influence of the Base Metal on the Structure of Electrodeposits, W. Blum and H. S. Rawdon - Trans. Ain. Electrochein. Soc. 44, 305 (1923).

C - Current Distribution and Throwing Power in Flectrodeposition. H. E. Haring and W. Blum - Trans, A.n. Flectrochem. Soc., 44, 313 (1923).

C - Principles of Throwing Power - Monthly Rev, Ain. Electroplaters' Soc. Aug. 1923.

C - The Crystaline Form of Flectrotenosited Metals, W. BIum and $\mathrm{H}$. S. Rawdon - Trans. Am. Flectrochem. Soc. 44, 397, (1923). 

Fubs. on Flectrodeposition fron

the Bureau of Standards - 2

$5 / 12 / 24$

C - Recent nrogress in Flectronlating and Flectroforming. W. Blun - Trans. Am. Flectrochen. Soc., 45 (1924).

II. Copper Denosition

B - Regulation of Flectrotyring Solutions. Bureau of Standards Circular C 52. Second Edition (1916). 10 cents.

C - Prelininary Studies in the Denosition of Copper in Electrotyping Baths. W. Blum, H. N. Holler and $\mathrm{H}$. S. Rawdon, Trans. An. Flectrochen. Soc. 30, 159 (1316).

B - Relation Between Composition and Density of Aqueous Solutions of Copper Sulphate and sulphuric Acid. H. D. Holler and F. L. Peffer. Bureau of Standards Scientific Paper S $275(1916)$. 5 cents.

\section{Zinc Deposition}

C - Zinc Cyanide plating Solutions, and C. M. Carson, Wonthly Rev. A.n. Electroplaters' Soc., Nov. 1918, Dec. 1918, and Anril 1919.

B - Same. Bureau of Standards Technologic Paner T 195 (1921). 5 cents.

\section{Lead Plating}

C - The Operation of Fluoborate Lead Plating Baths. "F.' J. Iiscoub, Z. Jencl:s and W. F. Bailey. Monthly Rev. Am. Electroplaters' Soc. Septenber 1919.

$C$ - Lead Plating fron Fluoborate Solutions, Tr. BIun, F, J. Liscomb, Z. Jencls and W. E. Bailey. Trans. Am. Flectrocher. Soc. 36, 243 (1919).

A - Abstract of nreceding article. Bureau of standards Letter Circular LC 34 ( 1921 ).

\section{Nickel Deposition}

A - The Use of Fluorides in Solutions for Nickel Deposition. W. Blun - Trans. An. Electrochen. Soc. 39, 459 (1921).

C - Principles Underlying the Acidity of Nickel Plating Solutions, T. Blum and $\mathrm{N}$. R. Thompson-konthly Rev. An. Electroplaters' Soc. Aug. 1921.

C - The Acidity of Nickel Depositing Solutions, $M . R$. Thompson, Trans. An. Flectrochem. Soc. 41, 333 (1922). 

Pubs. on Glectrodenosition from

the Bureau of Standards - 3

$5 / 12 / 24$

C - Control of Acidity in Nickel Deoosition - Monthly Rev. An. Flectronlaters' Soa. Decenber 1922.

A - Same - Bureau of Standards Letter Circular LC 82, (1922).

C - The Fffect of Inpurities in Niclel Salts Used for Electrodenosition, $M . R$. Thompon and $C . T$. Thonas - Trans. An. Filectrochem. Soc. 42, 79 (1922).

C - The Purity of Nickel Salts, M. R. Thomnson and C. T. Thomas - Monthly Rev. Am. Flectroplaters' Soc., Septenber 1922.

A - Saile. Bureau of standards Letter Circular JC 83 (1922).

C - The Effect of Iron on the EIectrodeposition of NickeI. M. R. Thomoson, Trans. An. Electrochen. Soc., 44, 359 $(1923)$.

C - Nickel Anodes - C. T. Thomas and N. Blum. Trans. An. Electrochen. Soc. 45, (1924).

C - Behavior of Mickel Anodes, C. T. Thomas and T. BIum, Wonthly Rev. Am. Electroplaters' Soc. Warch 1924.

A - Sane. Bureau of Standards Letter Circular LC 115 (1924).

C - Conductivity of Nickel nepositing Solutions, L. D.
Hamnond, Trans. An. Flectrochen. Soc. 45 (1924).

A - Abstract of preceding paner. Bureau of standards Letter Circular 120 (1924).

II. Black Nickel Plating

C - Black Nickel Plating Solutions. Geo. B. Hogaboon, T. F. Slattery and L. B. Ham. Monthly Rev. An. Electroplaters' Soc. July 1979.

B - Sane. Bureau of Standards Technologic Paner T 190 (1921). 5 cents.

VII. Miscellaneous

C - Wilitary Apolications of Flectronlating. W. Blum, Trans. Ara. Electrochen. Soc. 34, 169 (1918).

A - The Fnbrittling Fffects of Cleaning and Piclling upon Carbon Steels. S. C. Lengdon and i. A. Grossman. Trans. Ain. Electrochen. Soc. 37, 543 (1920). 

Pubs, on Flectroderosition from

the Bureau of Standards - 4

C - Specification of Electroplating for the Autonotive Industry, W. BIun, Autonotive Industries, June 16, 1289 (1921):

C - The Electrolytic Reproduction of Engraved Printing Plates. W. Blum and T. F. Slattery, Chem. \& Met, Eng. 25, 320 (1921).

C - The Electrodeposition of Lead-Tin Alloys, W. Blum and H. E. Haring, Trans. Am. Electrochem. Soc. 40, 287 (1921).

A - Abstract of preceding paper. Bureau of Standards Letter Circular LC 4 (192I). 
